\title{
The first fossils of the most basal pseudoscorpion family (Arachnida: Pseudoscorpiones: Pseudotyrannochthoniidae): evidence for major biogeographical shifts in the European paleofauna
}

\author{
Daniel Schwarze ${ }^{1,3} \cdot$ Danilo Harms $^{3} \cdot$ Jörg U. Hammel ${ }^{2} \cdot$ Ulrich Kotthoff $^{1}$ (D)
}

Received: 8 October 2020 / Accepted: 23 April 2021 / Published online: 22 June 2021

(c) The Author(s) 2021

\begin{abstract}
Pseudoscorpions belong to the oldest terrestrial lineages with origins in the Devonian (ca. $385 \mathrm{Ma}$ ) but their fossil record is extremely sparse and little is known about their diversification over time. Here, we describe the first fossil species of the pseudoscorpion family Pseudotyrannochthoniidae that resemble the Devonian fossils in major details, such as the chaetotaxy of the pedipalps. We describe two new species, Allochthonius balticus sp. nov. from Baltic amber and Centrochthonius bitterfeldicus sp. nov. from Bitterfeld amber in northern Europe. Both species can unequivocally be assigned to extant genera and provide further evidence for dramatic range shifts in European invertebrate biota since the Paleogene. Allochthonius Chamberlin, 1929 is a diverse genus in eastern Asia (China, Korea, and Japan) today but does not occur anywhere in central Asia, Europe or North America. Centrochthonius Beier, 1931 is a poorly known genus but seems to be restricted to high altitude habitats in central Asia (China, Kyrgyzstan, and Nepal). With range retractions to regions more than $4600 \mathrm{~km}$ away from the European amber deposits, the fossils highlight total lineage extinction in Europe and survival in refugia that are climatically and botanically most similar to the Baltic amber forest of the Eocene. Overall, our results support the concept of morphological but potentially also ecological stasis in major pseudoscorpion lineages over long periods of time and agree with previous studies that suggested a warm temperate rather than subtropical or tropical climate for the time of amber deposition.
\end{abstract}

Keywords Baltic amber $\cdot$ Bitterfeld amber $\cdot$ False scorpions $\cdot$ Heterosphyronida $\cdot$ New species $\cdot$ Synchrotron CT

\section{Introduction}

Pseudoscorpions (Arachnida: Pseudoscorpiones de Geer 1778) are a diverse order of arachnids with ca. 3700 extant species from all continents except Antarctica (Benavides et al. 2019). These animals are sometimes also referred to

Handling Editor: Mike Reich.

Ulrich Kotthoff

ulrich.kotthoff@uni-hamburg.de

1 Center of Natural History, Geological-Paleontological Museum and Institute for Geology, Universität Hamburg, Bundesstraße 55, 20146 Hamburg, Germany

2 Institute of Materials Physics, Helmholtz-Zentrum Hereon, Max-Planck-Straße 1, 21502 Geesthacht, Germany

3 Center of Natural History, Zoological Museum, Universität Hamburg, Martin-Luther-King-Platz 3, 20146 Hamburg, Germany as false scorpions because they resemble their large relatives but lack a sting and tail and are also a lot smaller (less than $1.5 \mathrm{~cm}$ in body length). Pseudoscorpions occur in a variety of habitats ranging from soil and leaf litter to tree bark, rocks, and even the seashore (Harvey et al. 2007; Anthony et al. 2016). Pseudoscorpions also belong to the oldest terrestrial lineages and fossils that look quite modern are already known from the Middle Devonian (Givetian) of Gilboa, some 385 Ma (Shear et al. 1989; Schawaller et al. 1991). These key fossils aside, there is a major gap of more than 250 million years between the Devonian compression fossils and amber inclusions from the Cretaceous of Myanmar (earliest Cenomanian, 99 Ma; see Shi et al. 2012) but also those from European succinite ambers, primarily Baltic and Bitterfeld amber (Beier 1937, 1947; Harms and Dunlop 2017; Ahrens et al. 2019). Presently, only 14 of the 25 recognised pseudoscorpion families have a fossil record (Fig. 1) but little can still be said about evolutionary changes over time because most of the amber species, in particular 


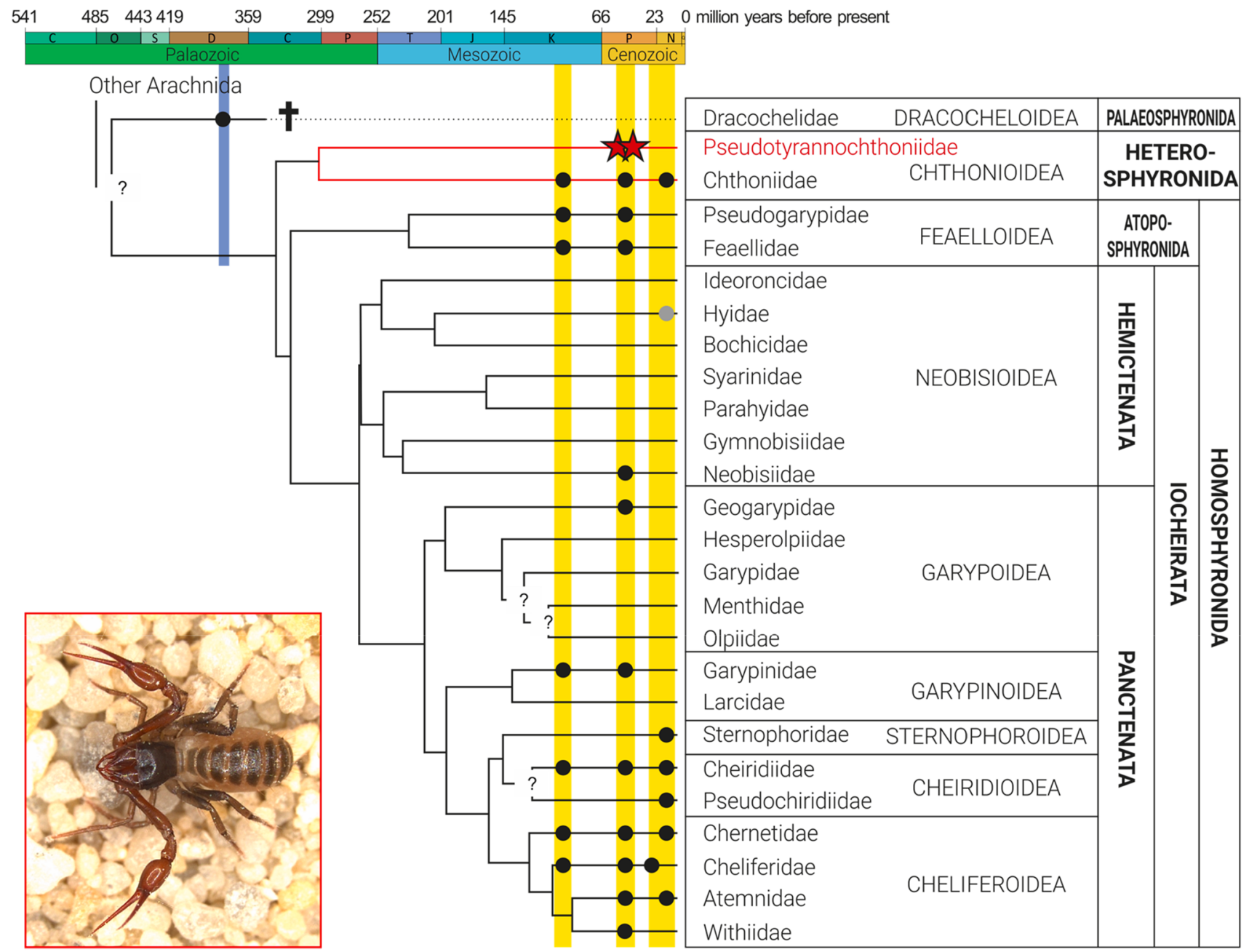

Fig. 1 Present pseudoscorpion phylogeny with dated fossils (black circles, new fossil members of Pseudotyrannochthonidae indicated with stars) and present-day Pseudotyrannochthonius giganteus Beier, 1971 from Warren National Park in Western Australia. A fossil belonging to the family Hyidae is documented by a photograph (Xia et al. 2015), but indicated with a grey point since it has not yet been described in detail

continental drift as a major driver of diversification (Harms and Harvey 2013; Harms et al. 2019). Fossil data support this scenario because the Palaeozoic pseudoscorpion Dracochela deprehendor Schawaller, Shear and Bonamo, 1991 from Gilboa shows a highly similar arrangement of the pedipalp trichobothria that is not shared by any other family, extinct or alive (Judson 2012). No pseudotyrannochthoniid fossils were known until Ahrens et al. (2019) recently illustrated (but did not describe) a specimen from Bitterfeld amber. This lack is surprising given that the sister family Chthoniidae Balzan, 1892 has a well-established fossil record with species known from the Cretaceous of Myanmar (Harvey et al. 2018; Wriedt et al. 2021), four species in Baltic amber (Harms and Dunlop 2017), several undescribed species in Bitterfeld amber (Ahrens et al. 2019), and four species from both Dominican and Mexican ambers of Miocene age (Schawaller 1980; Judson 2016). 
Pseudotyrannochthoniidae occur today on five continents and the ca. 50 described species are presently classified into five genera: Afrochthonius Beier, 1930 from South Africa, Madagascar and Sri Lanka, Allochthonius Chamberlin, 1929 from eastern Asia, Centrochthonius Beier, 1931 from central Asia, Pseudotyrannochthonius Beier, 1930 from Chile, Australia, eastern Asia, and the U.S.A, and Selachochthonius Chamberlin, 1929 from South Africa (Fig. 2). Most species occur in warm temperate or Mediterranean climates although there are a few records from subtropical (Madagascar) or cool temperate (Japan, Tasmania) regions. Centrochthonius is the only exception because its species occur in high-altitude habitats, often with regular snow (Harvey 2013). Generally, these pseudoscorpions are typical forestdwellers that have been sampled from moist leaf litter habitats (Benedict and Malcolm 1970; Harms 2018; Harms et al. 2019) although several species are cave specialists (Harvey 2013; Harms 2018; Harms and Harvey 2013).

In this paper, we establish the first fossil record for the family Pseudotyrannochthoniidae by describing two new species from European succinite ambers as Allochthonius balticus sp. nov. (Baltic amber) and Centrochthonius bitterfeldicus sp. nov. (Bitterfeld amber). Both species can unequivocally be assigned to modern genera from Asia, which has biogeographical implications and provides insights into distributional shifts of this family over time. The fossils also show that the diversification into present-day genera may have occurred long before the Paleogene, with relative morphological stasis in diagnostic features since then. Finally, we improve the fossil record for this order by documenting the $15^{\text {th }}$ of presently 25 recognised extant families and draw conclusions about the paleohabitat the fossil species most likely inhabited.

\section{European succinite ambers}

There are three major deposits of arthropod amber fossils in Europe which are often referred to as succinite ambers based on their high content of succinic acid relative to other amber types (Gough and Mills 1972). Baltic amber comes from a wide area at the Gulf of Gdansk and has been studied extensively for more than a century for its diversity of fossils (Dunlop et al. 2019). Bitterfeld amber, sometimes referred to as Saxon or Saxonian amber, is a smaller deposit and originates from near the town of the same name in eastern Germany. Rovno amber is from northwestern Ukraine (Klesov and Volnoje) and represents the third major deposit. Romanian amber (rumanite) is also a succinite that is thermally altered (Stout et al. 2000) but this deposit is rather small.

Baltic amber is still the primary source for pseudoscorpion fossils and presently yields 34 valid species in 12 families (Harms and Dunlop 2017). This amber can be found

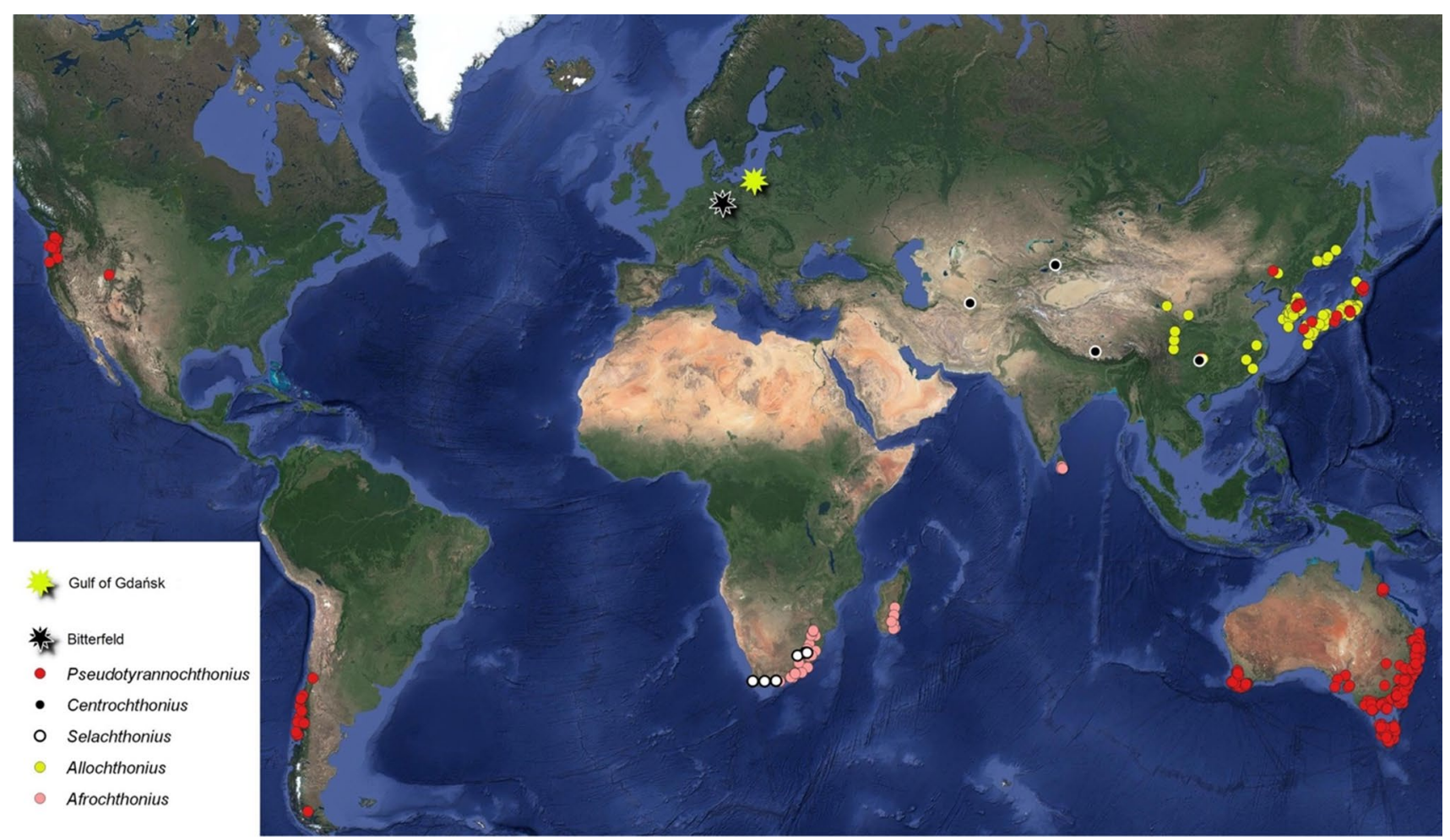

Fig. 2 Distribution of Pseudotyrannochthoniidae genera with colour-coding for each genus. The fossils are depicted in asterisks and records of extant relatives are given as circles 
all around the entire coast of the Baltic Sea along the Gulf of Gdansk although many inclusions are offered for sale from the Kaliningrad region of the Baltic coast of Russia. A range of published ages can be found in the literature but most authors tend towards an Eocene (Lutetian) age of about 44-49 Ma (Weitschat and Wichard 2010), although other researchers prefer a Priabonian age, ca. 37.8-34 Ma (Dunlop et al. 2019). Sadowski et al. (2017) recently conducted an extensive comparative analysis of conifer types and suggested a Late Eocene age (38-33.9 Ma) for the Baltic amber forest. They provided conclusive paleobotanical evidence for a mixed mesophytic conifer-angiosperm forest that thrived under humid warm-temperature rather than (sub)tropical conditions. Present-day analogues are the warm-temperate forests in East Asia and North America, especially southeastern China and the western USA.

Bitterfeld amber was mined commercially during the time of the German Democratic Republic and several groups of arthropods and plants were documented from this amber (e.g. Weitschat 2008). Amber mining ceased after the German reunification and the "Braunkohle" mine at Goitzsche from which most of the amber originated was flooded in 1998 as part of a landscape restoration project, also intended to increase touristic interest in this region. Recently, amber mining has commenced again and new inclusions are becoming available. There is an ongoing controversy about the geological age of this amber (reviewed in Dunlop et al. 2018) that is deposited in horizons of Upper Oligocene (Chattian, 23.0-28.1 Ma)/Lower Miocene age although the amber is likely reworked and could be significantly older. Emphasizing the similarity in amber fossils between Baltic and Bitterfeld ambers, some authors have suggested that the latter is merely a southerly outcrop of the wider Baltic amber forest (e.g. Szwedo and Sontag 2013) whereas others prefer an Oligocene or even Miocene age. Geochemical data show that Bitterfeld and Baltic amber differ (Wolfe et al. 2016) which is not surprising given that both deposits were at least for some time divided during the Eocene by a marine transgression (see Dunlop et al. 2018). Recently Mänd et al. (2018) suggested a roughly contemporaneous origin of all succinites based on stable isotope analyses and related the slight chemical differences between the three amber types to precipitation sources and mean annual temperatures of the amber source regions, with more southerly origins for both Bitterfeld and Rovno ambers compared to the Baltic deposits. Although the issue may not be totally resolved, the evidence presently points to an Eocene age for all succinite ambers, but also to compositional differences in both flora and fauna between the deposits that are reflective of local geography and climate. This could also explain why some invertebrate species appear to be widespread across all amber types whilst each of the deposits also seems to have some unique species.

\section{Pseudotyrannochthoniidae in the Northern Hemisphere}

Pseudotyrannochthoniidae are a lineage with enormous biogeographical research potential but unfortunately, research is hampered by a generic classification that is still in flux (Harms and Harvey 2013; Harms et al. 2019). Several genera are poorly defined as they stand (Harms and Harvey 2013); however, a generic revision is being prepared. From the literature, all species and genera in the Southern Hemisphere (Afrochthonius, Pseudotyrannochthonius and Selachochthonius) share the presence of 18 setae on the carapace and are thus set apart from the Northern Hemisphere fauna that is more variable. In the Northern Hemisphere the family presently comprises three genera: Allochthonius, Centrochthonius and Pseudotyrannochthonius.

Allochthonius is widely distributed and common in eastern Asia. It is easily diagnosed by the high number of setae on the carapace, usually between 18 and 30 (Gao and Zhang 2013; Fig. 3a), and a unique arrangement of coxal spines on the interior apical margin of the leg coxa I that are shaped like a "spray" or "fan" of 8-10 clavate spines (Fig. 3b); a feature that Chamberlin (1929) originally used to define this genus. Observations in the field suggest that these are grooming organs and used to clean the leg claws as well as the pedipalp fingers.

Centrochthonius is a poorly known genus that originally contained two species from high latitude habitats in Kyrgyzstan and Tibet (Redikorzev 1918, 1934). The description for both species is brief but the type species C. kozlovi has 16 setae on the carapace and a unique arrangement of the coxal spines, which are shaped as five short and tripartite spines with a sharp tip on a small protuberance at the internal margin of the pedipalp coxae (Redikorzev 1918: fig. 10c). Two additional species were added to this genus later (Beier 1979; Schawaller 1995) but they share all diagnostic features of Allochthonius and are clearly misplaced.

Pseudotyrannochthonius is also known from the Northern Hemisphere with 3 species from the western U.S.A and 4 species from caves in Japan and South Korea (Harvey 2013); the latter classified originally as a separate genus Spelaeochthonius Morikawa, 1954 that is currently placed in the synonymy of Pseudotyrannochthonius. These cave species and the American counterparts share with Centrochthonius the presence of 16 setae on the carapace and differ substantially from the type species of Pseudotyrannochthonius from Chile which has 18 setae on the carapace and a completely different arrangement of the coxal spines (Beier 1930). In fact, both the Asian cave and the American species seem closer to Centrochthonius, but the American species have eight to ten coxal spines with a spatulate tip that are arranged as a transverse, linear row (Fig. 3c; Muchmore 1967, Benedict and Malcom 1970). 
Fig. 3 SEM images of diagnostic features in Northern hemisphere genera. a carapace of Allochthonius tamurai Sakayori, 1999, a typical representative of this genus with 24 setae on the carapace (WAM T146407); b coxal spines of $A$. opticus (WAM T146482), the type species of the genus. Note that the coxal spines are arranged as a "spray" on the apical margin of the pedipalp coxa; $\mathbf{c}$ coxal spines of Pseudotyrannochthonius gracilis Benedict and Malcolm, 1970 from Oregon, USA (WAM T146426). They are arranged as a transverse row and removed from the apical margin of the coxa and resemble Centrochthonius that has fewer (4-5) spines with acute tips; and $\mathbf{d}$ Pseudotyrannochthonius dentifer (Morikawa, 1970) from South Korea. The coxal spines are also arranged as a row but the tips are plumose and elongate
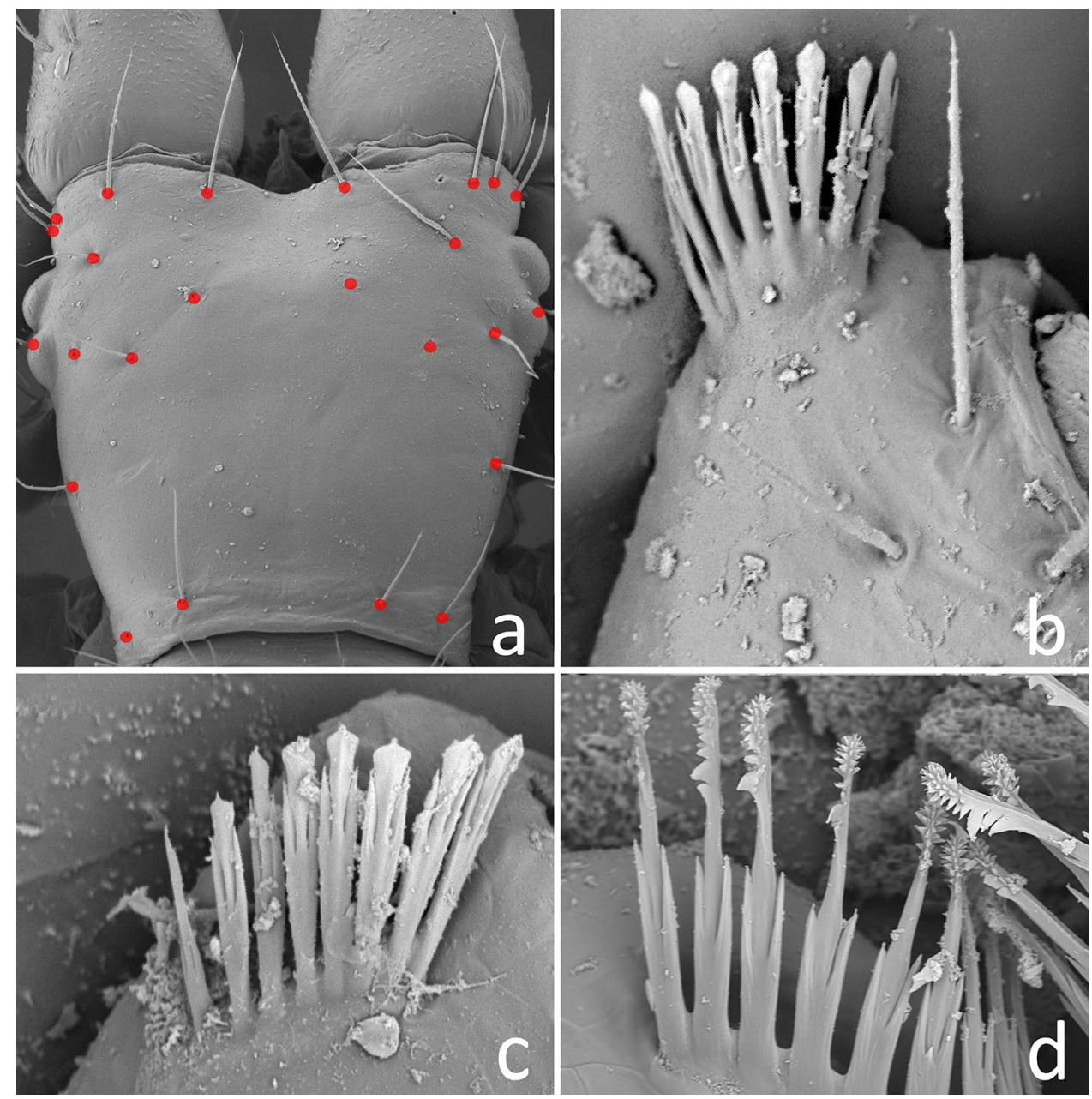

The Asian cave species can have even higher numbers of coxal spines and the tips are very elongate and distally plumose (Fig. 3d; Morikawa 1954: fig. 1F). It should be noted that Centrochthonius and these "Northern Hemisphere" Pseudotyrannochthonius also have an intercoxal tubercle that, however, is not as strongly developed as in Allochthonius.

Classification aside, Allochthonius is a common element of eastern Asian deciduous forest systems where species live in moist leaf litter. Distribution spans both warm temperate and cold temperate forests, such as all of the Japanese islands (Harvey 2013). Some species are also obligate cave dwellers without eyes but the typical features of this genus (coxal spines as a spray and $>18$ seta on the carapace) are still retained (Morikawa 1954, 1956, 1970). Centrochthonius seems to be restricted to high-altitude habitats in central Asia that receive regular snow and frost for many months of the year. Redikorzev (1934) recorded the Kyrgyz species from moss under conifers in a river gorge above $2100 \mathrm{~m}$ altitude, the type species from Tibet was collected from more than $3000 \mathrm{~m}$ above sea level, and Schawaller (1991) established a record from 3550-3650 m "in mixed forest with Betula and Rhododendron". The North American species currently classified as Pseudotyrannochthonius have been collected from moist leaf litter in lowland forests with maples, oaks, redwood and conifers where they are quite elusive (Benedict and Malcom 1970), or moss in forested canyons (Muchmore 1967). The Asian cave species altogether show a troglomorphic appearance, including the lack of eyes, and have been collected from the dark zone of caves (Morikawa 1956, 1970). They are replaced on the surface by species of Allochthonius.

\section{Materials and methods}

Two specimens were available for study that were retrieved during a comprehensive survey of pseudoscorpion inclusions from both museum and private collections: specimen GZG.BST.23850 from the Geowissenschaftliches Museum, Universität Göttigen (Germany) and Specimen S5955 from the private collection of Carsten Gröhn, Glinde (Germany). The latter specimen has been deposited in the collections of the Geologisch-Paläontologisches Museum, 
Universität Hamburg with collection number GPIH05038. The pieces (Fig. 4) were polished first by wet-sanding them with waterproof silicon carbid sandpaper of different grain sizes (Waterproof SiC, FEPA P \#120, \#1200, \#4000, Struers $\mathrm{GmbH})$. Pieces with cracks or splits were varnished and sealed with polyurethane resin (Acrüdur R40, Adolf C. C. Rüegg GmbH \& Co.) following Gröhn (2020). Images were taken using a BK PLUS Lab System by Dun, Inc. with the software Capture One Pro 9.3 64 Bit (Version 9.3.0.85) and a Canon EOS 7D with microscopic lens $(5 \times$ and $10 \times$ magnification) or a $65 \mathrm{~mm}$ macro lens. Images with the DUN system were taken in oil (Bübchen Baby Öl, Ewald Hermes Pharmazeutische Fabrik $\mathrm{GmbH}$ ) to improve light dispersion and reduce reflections. These images were also used as a template for illustrations and Photoshop CS6 (Adobe) was used to edit the images further. Measurements were taken with the Leica Application Suite X (Version 3.0.1.15878) software and a Leica M205 stereomicroscope and are expressed in millimeters (mm). Body measurements exclude the chelicerae. Terminology generally follows Chamberlin (1931) but for the legs and pedipalps, the terminology of Harvey (1992) was used. Allochthonius balticus was measured with MeshLab based on a 3D-model of the specimen with the same terminology.

Three-dimensional models of both fossils were developed from SR $\mu C T$ scans that were done at PETRA III in beamline P05 (operated by Helmholtz-Zentrum Hereon) at the Deutsches Elektronen Synchrotron DESY (Greving et al. 2014; Haibel et al. 2010) using a custom-developed 20 MP CMOS camera system (Lytaev et al. 2014). Amber pieces were mounted on sample stubs with beeswax and then rotated through the beam, with each scan roughly taking 20-50 min. Scanning parameters included an effective voxel size in the reconstructed volume of $2.54 \mu \mathrm{m}$, a scan energy of $18 \mathrm{keV}$, and a sample detector distance of $7.9999 \mathrm{~cm}$. The acquired scans were segmented using Amira software (Version 6.0.1). Scanning electron microscopy images of extant species were produced using a Hitachi TM4000 Tabletop Microscope (Hitachi High Technologies, Japan) after airdrying the specimens, mounting them on a stub with some glue, and gold-coating them. These specimens are held at the Western Australian Museum (WAM), Perth, Western Australia. The distribution map was produced using QGIS 3.4 (Creative Commons).

The pseudoscorpion specimen GPIH05038 was itself preserved together with a larger crane fly (Limoniinae) and an air bubble had formed between both animals during preservation that obstructed the ventral view on the pseudoscorpion. Specimen GZG.BST.23850 was in a better condition although the cuticle was darkened and translucent emulsions covered some body parts. Pseudoscorpion GPIH05038 could be three-dimensionally reconstructed, while no detailed model could be obtained for GZG.BST.23850 after two scans.

\section{Systematic Paleontology}

Order Pseudoscorpiones de Geer, 1778

Suborder Heterosphyronida Chamberlin, 1929

Superfamily Chthonioidea Daday, 1889

Family Pseudotyrannochthoniidae Beier, 1932

Remarks. Pseudotyrannochthoniidae is easily distinguished from its sister family Chthoniidae by the position of trichobothria $i b$ and $i s b$ on the hand of the pedipalp chela that are situated in a distal position near the base of the fixed finger whereas they are situated medially or sub-basally in Chthoniidae (Fig. 6d; Harms and Harvey 2013; Wriedt et al. 2021). Nymphs only have a single trichobothrium $i b$ in the same position as adult specimens. This is a unique feature and only shared with the fossil Drachochela deprehendor from the Devonian (Judson 2012). Other diagnostic features include the presence of an intercoxal tubercle (potentially a remnant of the sternum in other arachnid lineages; Fig. 10b) that is reduced in some of the genera, and the presence of coxal spines on leg coxa I only (e.g. Figs. 3b, 10c). Typically for members of the Chthonioidea, these animals lack venom glands and the tarsi and metatarsi on legs I and II are fused (Fig. 10f) whereas those of legs III and IV are not fused. Both fossils share the diagnostic features of this family. Moreover, both fossils are clearly adults because trichobothria $i b$ and $i s b$ are discernible.

Genus Allochthononius Chamberlin, 1929

Allochthonius balticus sp. nov.

Figures 4a, 4c, 5, 6, 7

Etymology. The specific epithet balticus refers to Baltic amber in which the holotype has been preserved.

Material examined. Holotype, probably male, in Baltic Amber (GPIH05038, former private collection Gröhn, S5955).

Diagnosis. Most similar to Allochthonius ishikawai Morikawa, 1954 from caves in Japan and A. ussuriensis (Beier, 1979) from Russia by having 20 setae on the carapace but differing by the presence of 4 eyes (absent in A. ishikawai) and lack of troglomorphic appearance (e.g. legs and pedipalp not elongated). Also differs from most other congeners by the presence of 16 acute and spaced teeth on the fixed and 15 acute and spaced teeth on the movable pedipalp finger. 
Description. Colour (Fig. 5a, b): yellow to pale brown.

Chelicerae (Fig. 6e, f) - hand with 5 setae; moveable finger with 1 seta. Galea absent, serrula interior and rallum not visible, serrula exterior present but covered by a white emulsion. Fixed finger with 1 large acute tooth and 6 smaller and uneven acute teeth. Moveable finger with 5 small rounded teeth. 1 lyrifissure near the base of the fixed finger, others not visible.

Pedipalp (Figs. 5a, 6c, d)-Femur 8.18, patella 2.36, chela 4.75 , hand 1.57 , finger $14.17 \times$ longer than broad; finger $1.93 \times$ longer than hand. Trichobothria $i b, i s b$ are situated near the base of the fixed finger. Fixed chelal finger with 7 trichobothria including the shorter duplex trichobothria $x s$ : $e t$ is closer to $x s$ than to $i t$, it and est closer together than $x s$ and $e t$. Moveable chelal finger with 4 trichobothria. Distance of $s t$ to $s b$ about two times as long as the distance between the other trichobothria on the moveable finger. Chelal teeth: fixed finger with 16 acute teeth, distally the last 3 teeth are less acute. Moveable finger with 15 acute teeth of roughly the same size. Tubercle on moveable finger not visible if present.

Cephalothorax (Fig. 6a, b) —carapace 1.21 times longer than broad. Epistome absent, 2 pairs of well-developed eyes with a lens, first pair $0.06 \mathrm{~mm}$ in diameter, second pair slightly smaller with $0.05 \mathrm{~mm}$ in diameter. 20 setae arranged 8: $4: 4: 2: 2$, length of the setae roughly the same.

Coxal area (Fig. 7d) — covered by white emulsion and not visible using light microscopy. Coxal spines present on the apical inner margin of coxa I visible in the $3 \mathrm{~d}$ model and spray-shaped but the exact shape of spines cannot be determined. Intercoxal tubercle present (Fig. 7c) and dropshaped, setae not visible. Other details not visible.

Abdomen (Fig. 7a, b) -length: 1.36, width: 0.78. Tergites undivided, setae acuminate. Chaetotaxy of tergites I-IX: 4: 5: 6: 7: 7: 7: 9: 9: 5. Sternite chaetotaxy not visible. The 3D model reveals the anterior genital operculum (Fig. 7e, red dashed line) and a large triangular depression (red line) reminiscent of the male genital opening in males.

Dimensions (in mm, ratios in parentheses). body length 1.87; carapace $0.51 / 0.42(1.21 \mathrm{x})$; chelicera $0.44 / 0.21$ (2.10x); moveable finger 0.23/0.02 (11.5x). Pedipalp: trochanter $0.16 / 0.13(1.23 \mathrm{x})$; femur 0.90/0.11 (8.18x); patella $0.33 / 0.14$ (2.36x); chela 1.33/0.28 (4.75x); hand $0.44 / 0.28$ $(1.57 \mathrm{x})$, finger $0.85 / 0.06(14.17 \mathrm{x})$. Leg $\mathrm{I}$ : trochanter
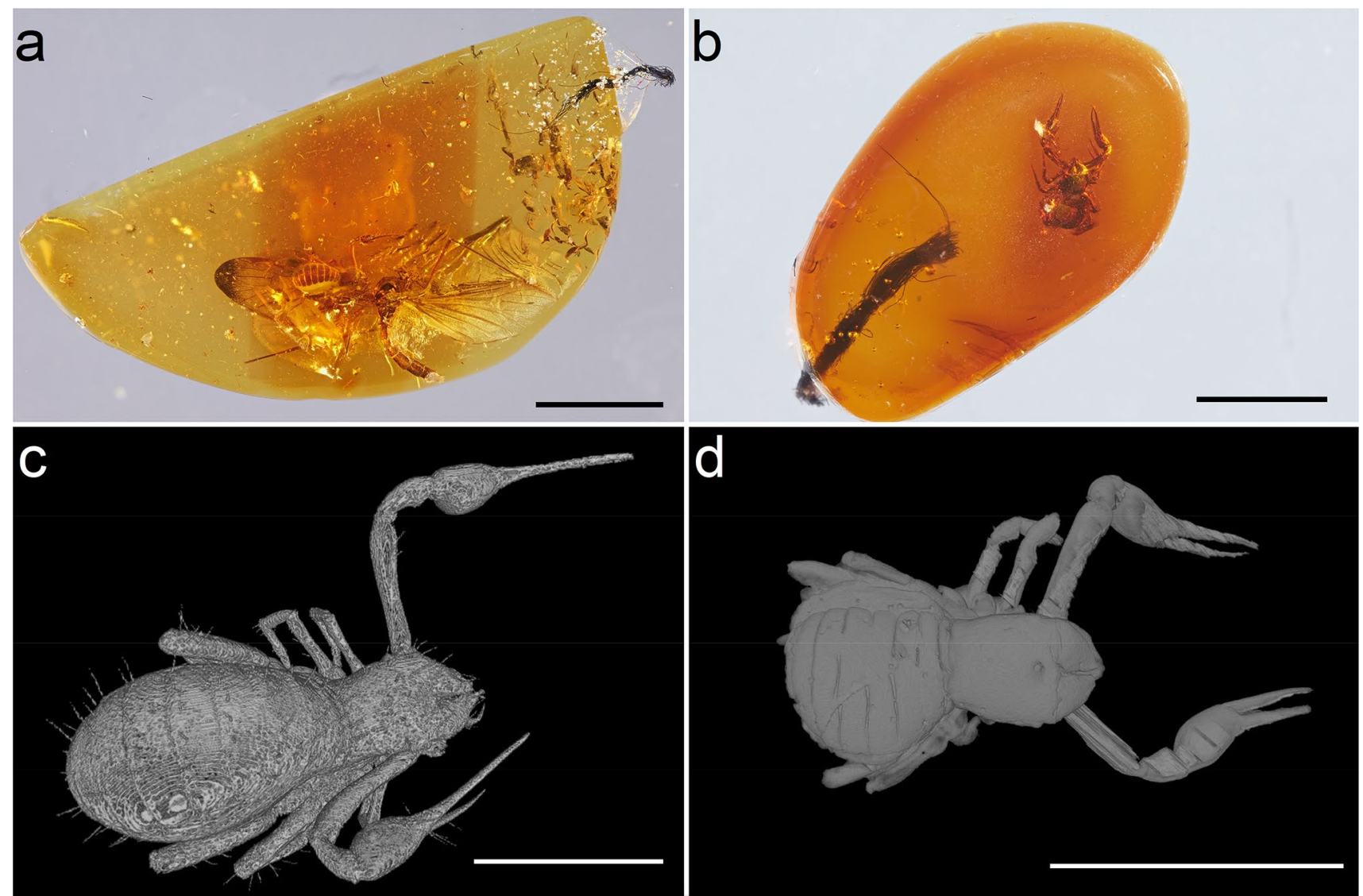

Fig. 4. Amber pieces examined as part of this study and 3D models retrieved from the Synchrotron scans. a piece S5955 with the holotype of $A$. balticus sp. nov. (scale bar $=4 \mathrm{~mm}$ ) and b piece GZG.

BST.23850 with the holotype of $C$. bitterfeldicus sp. nov. (scale $\mathrm{bar}=2 \mathrm{~mm}$ ); $\mathbf{c}$ model of $A$. balticus and $\mathbf{d}$ model of $C$. bitterfeldicus (scale bars $=1 \mathrm{~mm}$ ) 

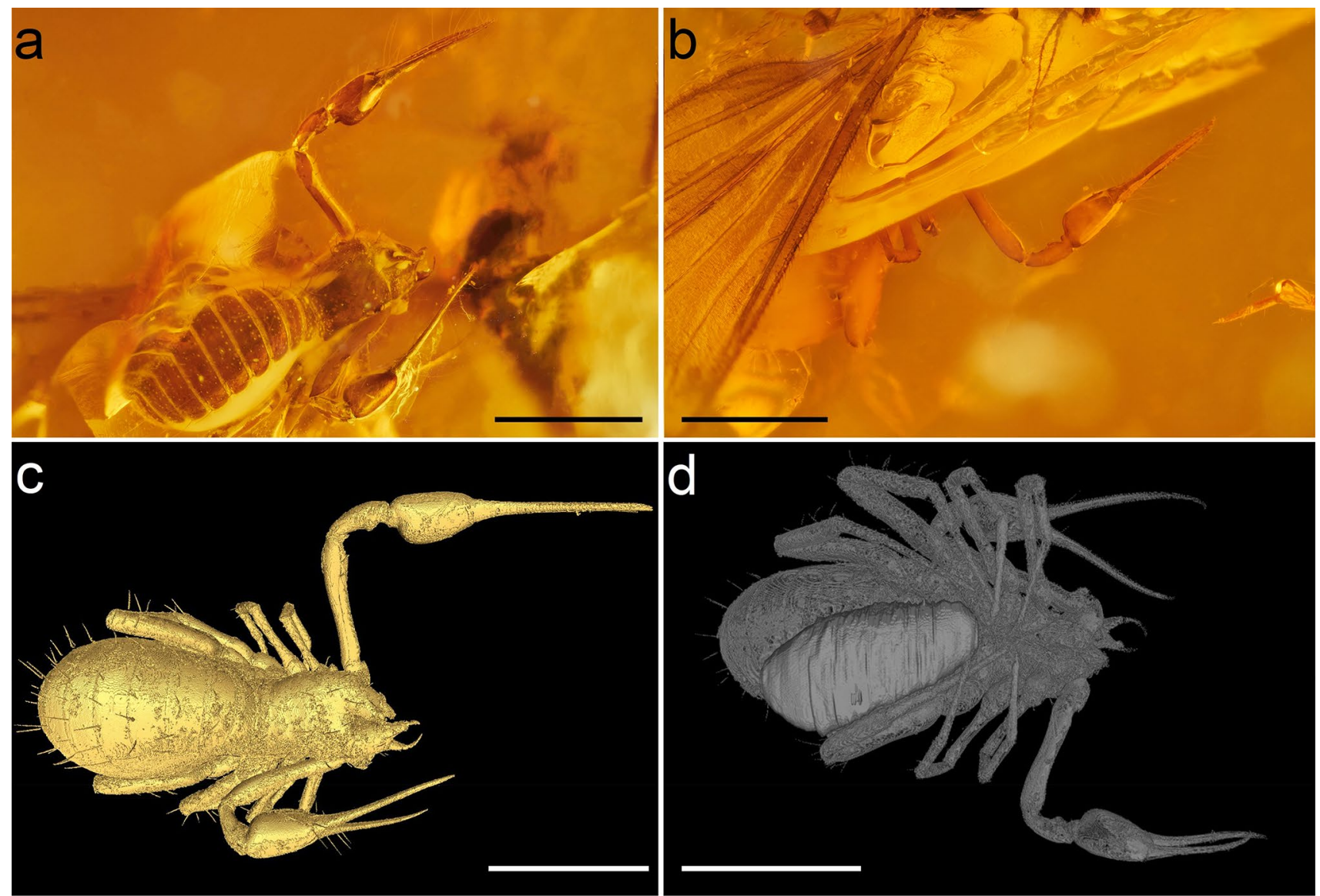

Fig. 5 Holotype of A. balticus sp. nov. (S5955). a photograph in dorsolateral view; b same in ventral view showing major obstructions: $\mathbf{c}$ model in dorsal view, and $\mathbf{d}$ model in lateral view showing obstruction (air bubble). All scale bars $=1.0 \mathrm{~mm}$

$0.20 / 0.14(1.43 x)$; femur $0.47 / 0.08$ (5.88x); patella $0.28 / 0.07(4 \mathrm{x})$; tibia $0.26 / 0.06(4.33 \mathrm{x})$; tarsus $0.47 / 0.04$ (11.75x). Leg IV: the border between trochanter and femur could not be seen; patella $0.63 / 0.18(3.5 \mathrm{x})$; tibia $0.37 / 0.09$ (4.11x); tarsus $0.26 / 0.06(4.33 \mathrm{x})$; metatarsus $0.49 / 0.04$ $(12.25 \mathrm{x})$.

Remarks. Although the exact shape of the coxal spines cannot be seen in the fossil, it shares the apical position of these spines that is diagnostic for Allochthonius and the high number of setae on the carapace, albeit being in the lower range for this genus (24-28 is the most common combination). In this context we also transfer Centrochthonius ussuriensis Beier, 1979 from Primorsky Kray in Russia to Allochthonius, forming the new combination of Allochthonius ussuriensis (Beier, 1979) comb. nov. because this species has 20 setae on the carapace (Beier noted 18 in the original description but this is a lapsus) and 7-8 coxal spines on a common protuberance at the apical margin of the coxa. Lastly we confirm the recent transfer of Allochthonius sichuanensis (Schawaller, 1995) from Centrochthonius (Hu and Zhang 2011) because it has 26 carapace setae and 9-10 coxal spines on a common protuberance. Both species showcase the confusion about generic assignments that will hopefully be resolved through the detailed diagnoses for both genera that are given herein, but also by fixing past identification errors.

\section{Genus Centrochthonius Beier, 1931}

\section{Centrochthonius bitterfeldicus sp. nov.}

Figures 4b, 4d, 8, 9, 10

Etymology. The specific epithet bitterfeldicus refers to Bitterfeld amber in which the holotype has been preserved.

Material examined. Holotype, female, in Bitterfeld amber (GZG.BST.23850; coll. M. Kutscher). Previously identified as Pseudoscorpiones: Chthoniidae.

Diagnosis. Differs from the extant species Centrochthonius kozlovi Redikorzev, 1918 and C. cheni Gao, Zhang and Zhang, 2016 comb. nov. by the presence of 4 short and 
Fig. 6 Models and illustrations of A. balticus sp. nov. (S5955). a 3D model of carapace in dorsal view and $\mathbf{b}$ carapace illustrated (scale bars $=0.5 \mathrm{~mm}$ ): c modeled pedipalp chela in lateral view; $\mathbf{d}$ chela illustrated (scale bars $=1.0 \mathrm{~mm}$ ); e modeled chelicera in lateral view: and $\mathbf{f}$ same structure illustrated (scale bars $=0.25 \mathrm{~mm}$ )
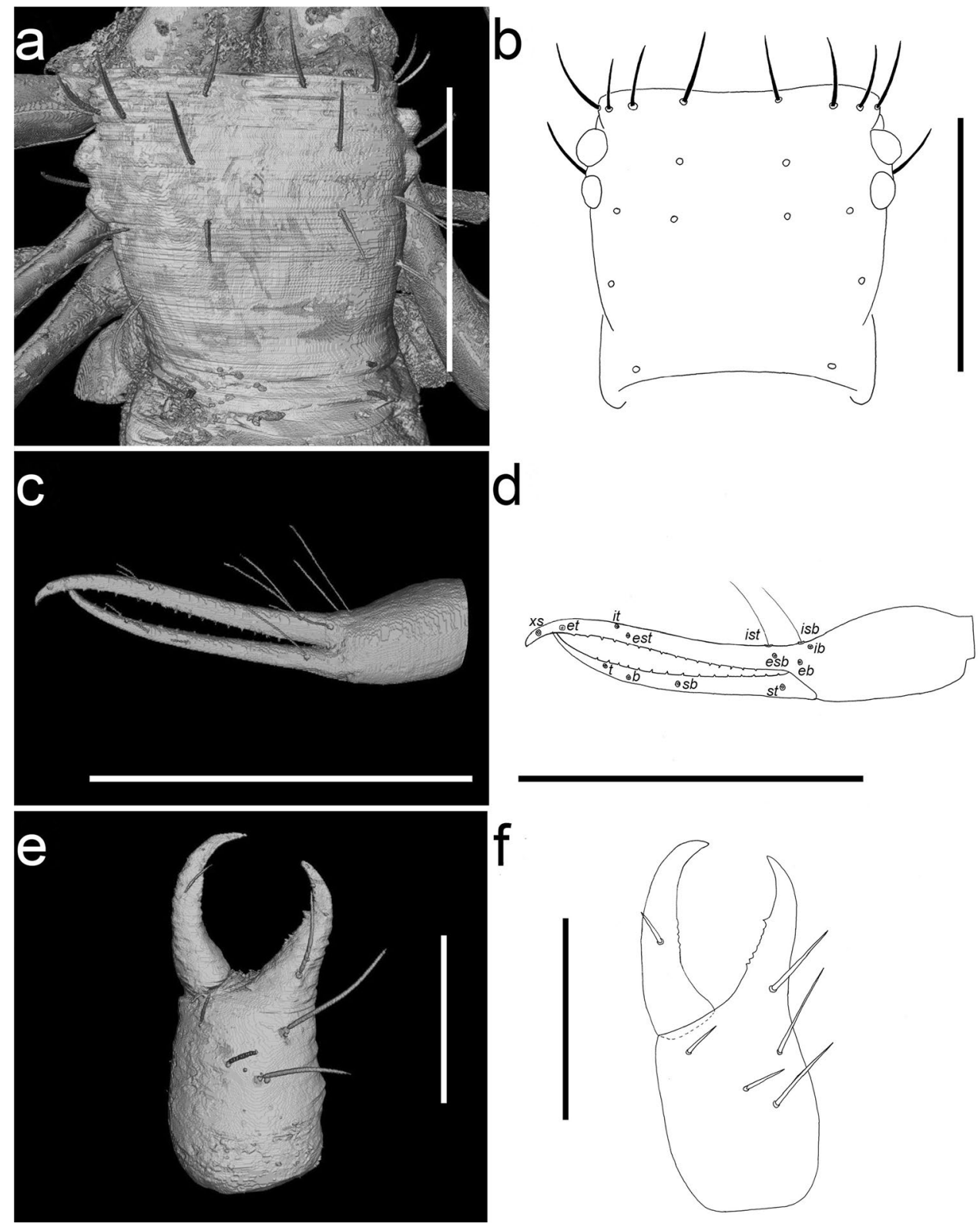

tripartite coxal spines (5 in C. cheni and C. kozlovi), small body size (0.89 in C. bitterfeldicus, 1.68 in $C$. cheni and 2.45 in C. kozlovi), and number of teeth on the fixed chelal finger (11 in C. bitterfeldicus, 16 in C. cheni and ca. 25 in C. kozlovi). Most similar to C. schnitnikovi Redikorzev, 1934 in having 4 coxal spines but much smaller (body length $2.0 \mathrm{~mm}$ ) and with a higher number of setae on tergites (up to 8 instead of 6 in C. schnitnikovi).

Description. Colour (Figs. 4b, 8a, c): pale to dark brownish.

Chelicerae (Fig. 9e, f) — hand with 4 setae; moveable and fixed finger with 1 seta, galea absent, rallum, lyrifissures, serrula interior, and serrula exterior not visible. 1 large apical tooth on the fixed finger, other teeth not visible.

Pedipalp (Fig. 9c, d)-femur 3.6, patella 1.2, chela 4.66, hand 1.41 , finger $11,5 \times$ longer than broad; Finger $1.92 \times$ longer than hand. Trichobothria $i b, i s b$ situated near the base of the fixed finger, roughly at the same height as ist. Fixed chelal finger with 7 trichobothria including the shorter duplex trichobothria $x s$, est and it as far away from $e s b$ as they are to et; est and is situated in the middle of the fixed finger; moveable chelal finger with 4 trichobothria: these roughly equidistant. Chelal teeth: fixed finger with 11 acute and widely spaced teeth, distal teeth slightly larger. 
Fig. 7 Abdomen and ventral view of Allochthonius balticus sp. nov. (S5955). a photograph of the abdomen and $\mathbf{b}$ 3D model of the same (scale bars $=1.0 \mathrm{~mm}$ ): $\mathbf{c}$ leg coxae II and IV in ventral view with the intercoxal tubercle highlighted in red; $\mathbf{d}$ genital area showing the anterior genital operculum (black dashed line) and genital opening (dashed red line); e coxal spines on leg coxa (scale bars $=0.25 \mathrm{~mm}$ )
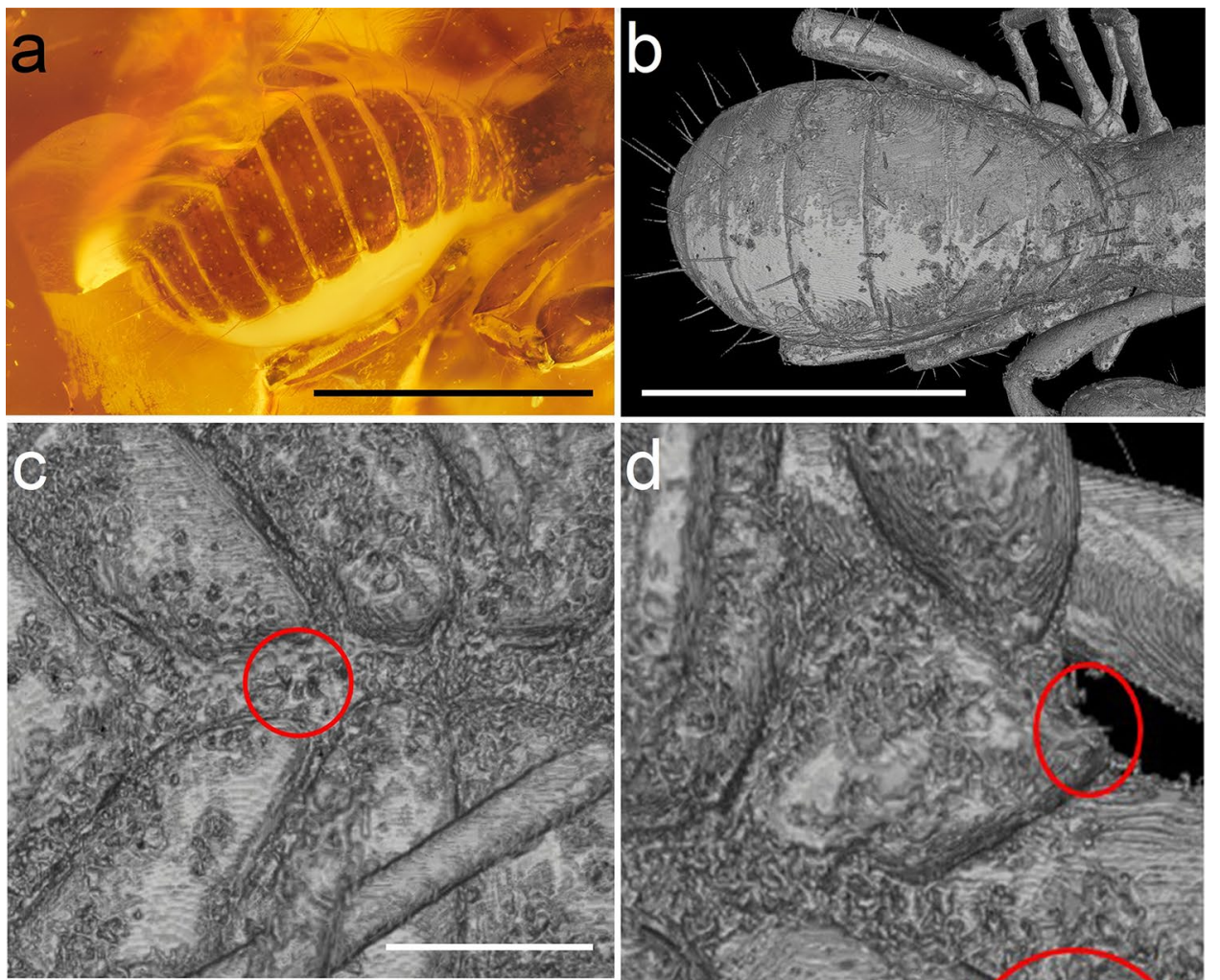

C.
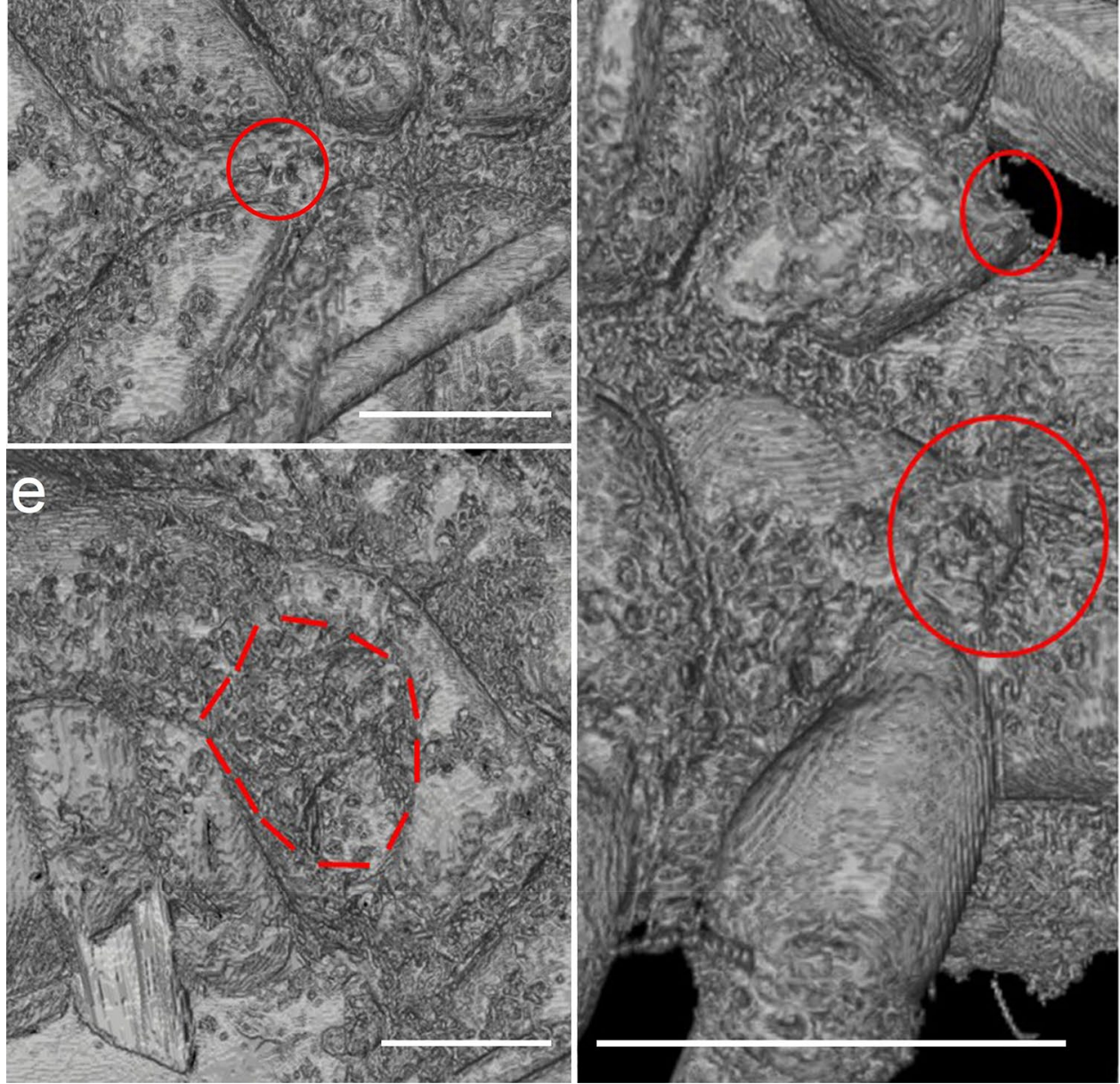

Moveable finger with 3 visible teeth in the distal third that is broader, flatter and widely spaced; some serrations more proximal.

Cephalothorax (Fig. 9a, b) - carapace 1.22 times longer than broad, ocular width 1.1 times wider than posterior width. Epistome prominent and serrate, 2 pairs of eyes, first pair well developed $(0.04 \mathrm{~mm}$ in diameter), vaulted and with a lens but second pair smaller, without a lens but adorned with 1 seta. Lyrifissures not visible. 16 setae arranged 6: 4: 2: $2: 2$, the posterior medial pair of setae seems to be longer than the rest but not all setae are preserved.
Coxal area (Fig. 10a, b, c, d) - tip of manducatory process with 2 acuminate distal setae, apical setae straight and about two times longer, setae on coxa hardly visible but pedipalp coxa with at least 3 setae, lyrifissures not visible, coxae 2, 3 and 4 with up to four setae. Intercoxal tubercle present but small and with 2 setae. Coxa I with 4 coxal spines on the inner margin, individual spines short, tripartite, and with acute tips; all spines in an oblique row without protuberance; removed from the anterior margin of the carapace.

Abdomen (Fig. 8a, b, c)-length $0.56 \mathrm{~mm}$, width $0.44 \mathrm{~mm}$. Tergites undivided, setae acuminate. Chaetotaxy 
of tergites I-VIII: $2: 6: 6: 6: 6: 8: 8: 8: 5$. Setae of other tergites not visible. Chaetotaxy of sternites could not be determined due to the preservation of the fossil, genitalia region darkened but the triangular opening of male chthonioids is not visible. The specimen is most likely female.

Legs (Fig. 10e, f) - Claws simple and not modified. Arolium undivided and shorter than the claws. Metatarsus and tarsus fused on legs I and II. Tactile seta on tarsus of leg IV present.

Dimensions (in mm, ratios in parentheses). body length 0.89 ; carapace 0.33/0.27 (1.22x); chelicera 0.22/0.14 (1.57x); moveable finger $0.15 / 0.02(7.5 \mathrm{x})$. Pedipalp: trochanter $0.11 / 0.09$ (1.22x); femur 0.36/0.1 (3.6x); patella 0.12/0.1 $(1.2 \mathrm{x})$; chela $0.7 / 0.17(4.11 \mathrm{x})$; hand $0.24 / 0.17(1.41 \mathrm{x})$, finger 0.46/0.04 (11.5x). Leg I: trochanter 0.1/0.08 (1.25x), femur $0.2 / 0.05(4 \mathrm{x})$; patella $0.13 / 0.05$ (2.6x); tibia $0.25 / 0.03$ $(8.33 \mathrm{x})$; tarsus $0.1 / 0.04(2.5 \mathrm{x})$. Leg IV: trochanter, femur, and patella not fully visible; tibia $0.23 / 0.05(4.6 \mathrm{x})$; tarsus 0.23/0.03 (7.67x); metatarsus 0.1/0.04 (2.5x). Dimensions of leg IV could not be determined precisely due to preservation.

Remarks. Centrochthonius bitterfeldicus is substantially smaller than any other species of this genus, but also smaller than all species of Pseudotyrannochthonius from Asia or North America that typically range from 1.5 to $3.0 \mathrm{~mm}$ in body length (Muchmore 1967; Morikawa 1956). Apart from size differences, it shares with these species a rather small intercoxal tubercle and the low number of tripartite and stout coxal spines; a feature that is unique to all central Asian species known to date. We also note that Pseudotyrannochthonius cheni Gao, Zhang and Zhang, 2016 is presently misplaced. It shares with C. kozlovi, the type species of the genus, a similar shape of the coxal spines (5 short and tripartite spines with a sharp tip). C. cheni was described from high elevations (2214 m altitude) at Mt. Fenghuang Shan in central China, habitats that resemble those of Centrochthonius kozlovi and C. schnitnikovi from central Asia. It is clearly not related to the type species of Pseudotyrannochthonius from Chile but also differs from the Asian karst species that have a higher number of coxal spines with plumose tips. This species is re-classified here as Centrochthonius cheni (Gao, Zhang and Zhang, 2016) comb. nov. and this leaves three extant species from highland habitats in central and eastern Asia, plus the $C$. burmiticus sp. nov. as the sole representatives of this genus. The genus co-occurs with Allochthonius in eastern Asia (but not central Asia) but the latter is presently restricted to lowland forest systems and some caves in Japan and South Korea (Morikawa 1954, 1956).

\section{Discussion}

\section{Biogeography}

The faunal paucity of the central and northern European biota relative to other regions in the Northern hemisphere
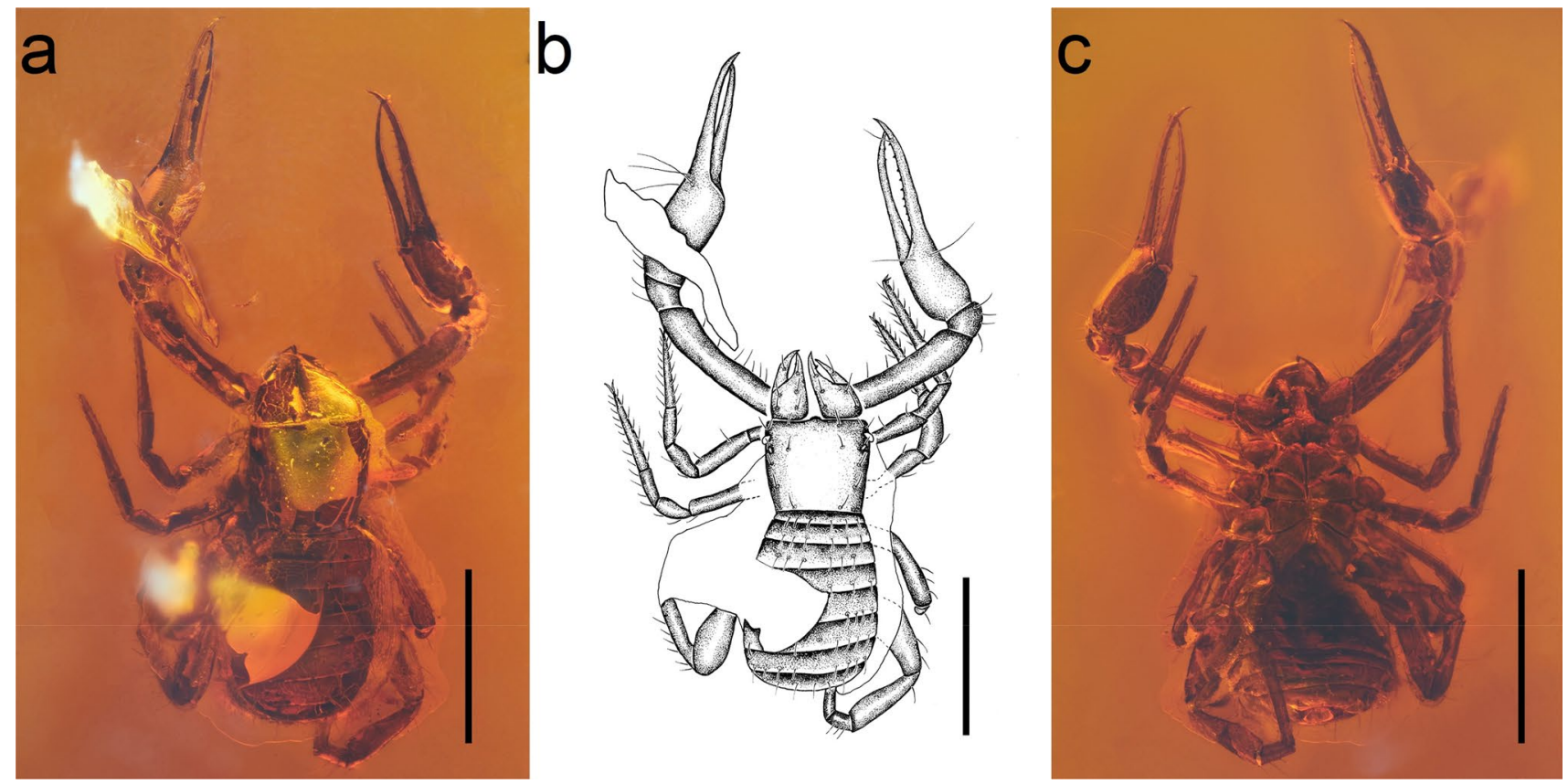

Fig. 8 Holotype of $C$. bitterfeldicus sp. nov. (GZG.BST.23850). a image of dorsal view: b interpretative illustration of the same: $\mathbf{c}$ image of ventral view. All scale bars $=0.5 \mathrm{~mm}$ 
Fig. 9 Images and illustrations of $C$. bitterfeldicus sp. nov. (GZG.BST.23850). a image of carapace in dorsal view: b carapace illustrated (scale bar $=0.25 \mathrm{~mm}$ ); c image of chela in lateral view; d chela illustrated (scale bars $=0.25 \mathrm{~mm}$ ); e image of chelicera in dorsolateral view; and $\mathbf{f}$ illustration of the same in lateral view (scale bars $=0.1 \mathrm{~mm}$ )
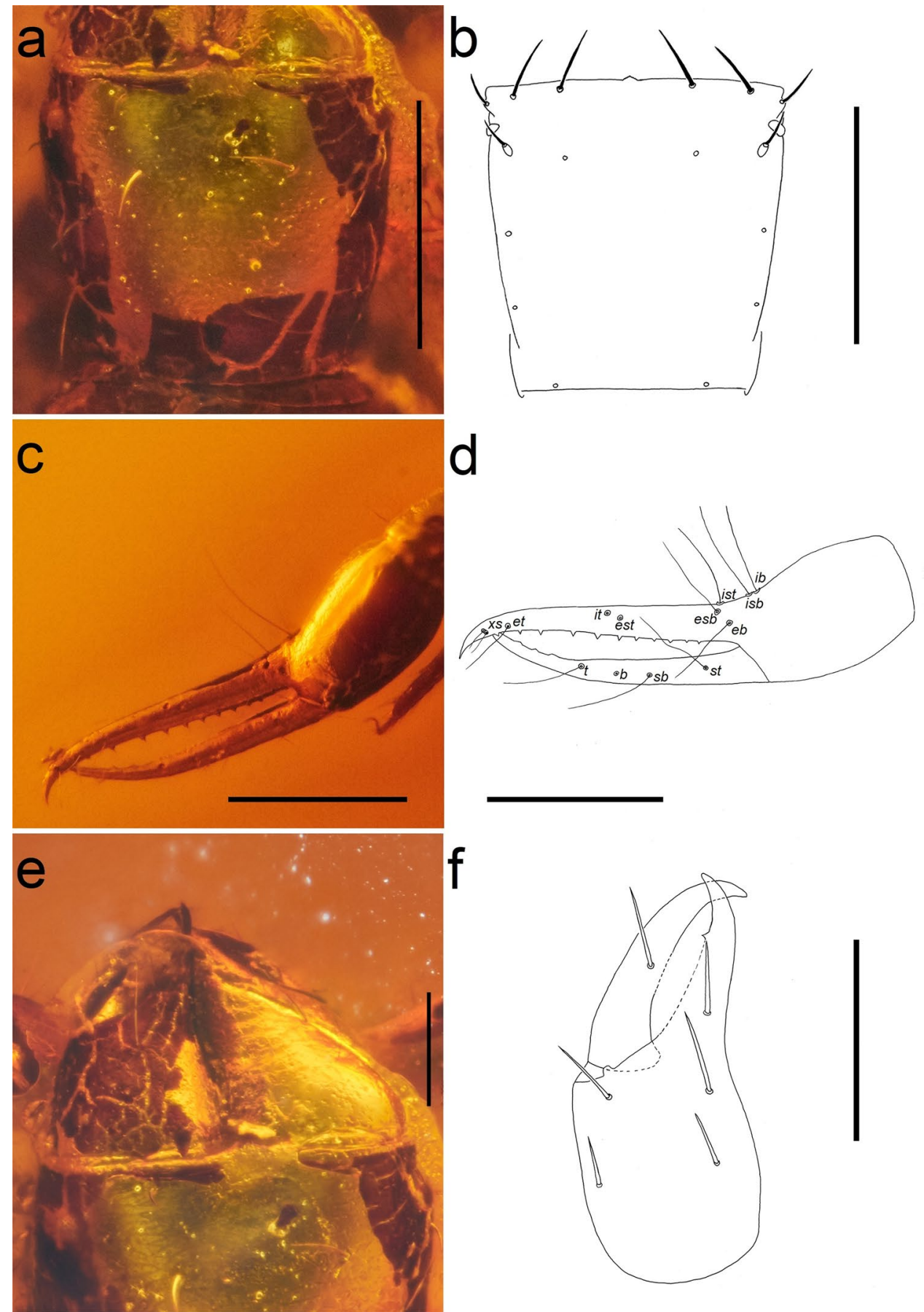

is often explained by excessive Pleistocene glaciation and range retraction of warm temperate faunal elements to the Mediterranean region, most notably the Iberian Peninsula, southern Italy, and the Balkans (e.g. Schmitt and Varga 2012). This is reflected in the composition of the succinite arachnid fauna that preserves taxa from southern Europe of today, including camel spiders, scorpions, and some of the mite and harvestmen taxa (Dunlop et al. 2004; Dunlop and Mitov 2009, 2015). The pseudoscorpion fauna is no exception and several families in amber are absent in central Europe today, but diverse in the Mediterranean such as the Geogarypidae (genus Geogarypus), Garypinidae (genus Garypinus) or some of the Neobisidae genera (e.g. Roncus) (Table 1). These obvious patterns aside, there are also many amber taxa that are extinct in Europe today but have living relatives in Asia, North America, or even the Southern Hemisphere. Pseudotyrannochthoniidae belongs to the former category with living relatives in Asia distributed more than $4600 \mathrm{~km}$ (Centrochthonius) or even $6000 \mathrm{~km}$ (Allochthonius) apart from the succinite deposits. In fact, 
the pseudoscorpion paleofauna features all possible biogeographical modes related to Neogene cooling events, such as retraction to the Southern Hemisphere (family Feaellidae: Feaella) (Henderickx and Boone 2014), warm temperate forests and caves in North America (Pseudogarypidae: Pseudogarypus) (Beier 1937; Harvey and Štáhlavský 2009) and total lineage extinction (e.g. Cheliferidae: Dichela and Electrochelifer). The closest match for Pseudotyrannochthoniidae would be the neobisiid genus Microcreagris with present-day species in both East Asia, and North America, and one fossil species from Baltic amber (Schawaller 1978; Harvey 2013).

Major range shifts in lineage distributions are not uncommon in an ancient lineage such as pseudoscorpions where several taxa have bipolar distributions and closely related species occur e.g. Tasmania and North America but nowhere else, which is a result of major extinction over long periods of time (Harvey 1998; Harvey and Šláhlavský 2009). More interesting is the search for causes and modes of retraction, in particular, if these are shared amongst invertebrate groups such as between Pseudotyrannochthoniidae and Hyleoglomeris pill millipedes. The latter are also diverse in Asia today and have recently been recorded from Baltic amber (Wesener 2019). Climatic shifts are the most likely explanation for the significant turnover in European paleobiota and pseudoscorpions can help to evaluate several hypotheses related to these biotas. Traditionally the "Baltic amber forest" has been interpreted as a dense tropical forest but recent botanical analyses have opposed this long-held view and rather suggested a complex forest mosaic that thrived under warm temperate and humid conditions (Sadowski et al. 2017). Analogues would be the warm temperate forest systems of the western U.S.A. and southeastern China today. The pseudoscorpions clearly support this hypothesis because several lineages that are absent in Europe today are either persisting in the warm temperate forest refugia of eastern Asia (Pseudotyrannochthoniidae, Microcreagris) or the United States in North America (Pseudotyrannochthoniidae, Pseudogarypidae, Microcreagris). Note also that pseudoscorpion families that are exclusive to subtropical or tropical climates (e.g. Ideoroncidae) have not yet been recorded from any of these ambers to date, which follows the pattern of other arachnid orders such as whip spiders, whip scorpions, ricinuleids and schizomids that are also absent in succinites.

\section{Paleohabitats and ecology}

A recent analysis of conifers provided conclusive evidence for a warm temperate Baltic amber forest including coastal swamps, riparian forests, and diverse mesophytic coniferangiosperm assemblages with cypresses (family Cupressaceae), pines (Pinaceae) and now extinct types of conifers (Geinitziaceae) (Sadowski et al. 2017). There was also a low diversity of ferns that is reflective of temperate ecosystems (Sadowski et al. 2019) and atmospheric humidity was likely high. Analogues to these forests are found today in East Asia and North America, particularly southeastern Asia and along the west coast of the United States but also North Florida and Southeast Georgia. Pseudotyrannochthoniidae occur in both regions today but nowhere else in the Northern Hemisphere except for the sparse and relictual occurrences of Centrochthonius in central Asia. Obviously, these pseudoscorpions are dependent on such ecosystems and retracted to climatic refugia, as did the forests. Pseudotyrannochthoniidae are most diverse in China and Japan (Harvey 2013) today and several species appear to be common in moist leaf litter habitats (Hong et al. 1996). Seasonal shifts in abundance occur in colder habitats but specimens can be found in leaf litter all year round (Lee and Seo 1995; Hong et al. 1996). High rainfall regimes are a key factor and no species has ever been sampled from dry or semi-dry areas. Based on the available data for extant Allochthonius, the fossil A. balticus lived in moist leaf litter in rather dense forests, as suggested by the presence of two corneate eyes. This forest was likely closed, the climate was temperate, and rainfall was almost certainly high. All extant species of Centrochthonius have been sampled from upland habitats with regular frost and snow (Redikorzev 1918, 1934). However, the present-day distribution of Centrochthonius seems to be relictual, the generic classification of this genus and "Pseudotyrannochthonius" in the Northern Hemisphere (all sharing 16 setae in the carapace) is poorly resolved, and close relatives from North America occur in the warm mesic forests of Oregon, Washington and northern California (Benedict and Malcolm 1970). Thus, the seeming discrepancy between paleo- and extant biology of Centrochthonius may be resolved by future studies.

An interesting aspect is that Pseudotyrannochthoniidae seem to be rare in succinate ambers relative to other pseudoscorpions, even those with a similar ecology such as the chthoniids that are quite common and diverse (Ahrens et al. 2019). This is somewhat against the present-day pattern of Allochthonius in eastern Asia but follows the pattern of Pseudotyrannochthonius in the U.S.A. where all species are elusive relative to other pseudoscorpions (Benedict and Malcolm 1970). Ecological rather than climatic reasons have been suggested as a possible cause and interspecies competition may be a major factor that explains rarity in some of the lineages relative to others. This family was probably neither diverse nor common in the Eocene forests of Europe where it may have been outcompeted by the more common families Chthoniidae, Geogarypidae, and Neobisiidae.

\section{Evolution and molecular dating}

The recent availability of a dated transcriptomic phylogeny for pseudoscorpions (Benavides et al. 2019) offers exciting 
Fig. 10 Images and illustrations of $C$. bitterfeldicus sp. nov. (GZG.BST.23850). a image of leg coxae (arrow points to the intercoxal tubercle): $\mathbf{b}$ illustration of the same (scale bars $=0.25 \mathrm{~mm}$ ); $\mathbf{c}$ image of the leg coxae I in ventral view with black circle depicting the coxal spines (scale bar $=0.05 \mathrm{~mm}$ ); d illustration of the same (scale bar $=0.01 \mathrm{~mm}$ ); e image of leg I in ventral view and $\mathbf{f}$ illustration of the same (scale bars $=0.25 \mathrm{~mm}$ )
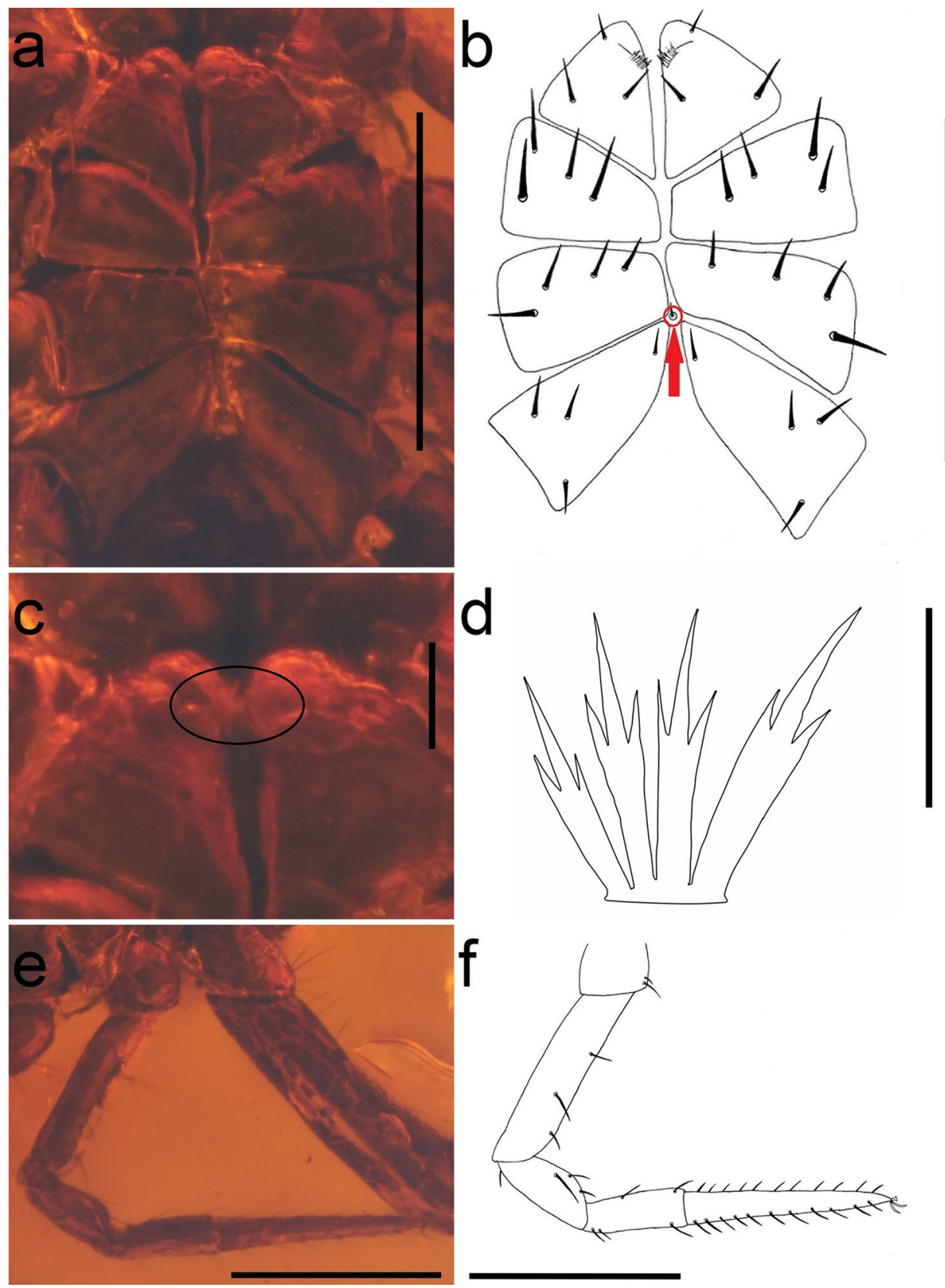

possibilities to evaluate aspects of morphological evolution over time. From this analysis the diversification into most families was completed by the Cretaceous and the most basal families, Pseudotyrannochthoniidae and Chthoniidae, split sometime between the Upper Devonian (ca. $370 \mathrm{Ma}$ ) and the Middle Triassic (250 Ma). This means that present-day genera were probably well established before the Paleogene (66-23 Ma), a hypothesis that may also be supported by distribution patterns that suggest continental drift as a main cause of diversity in this lineage (Harms and Harvey 2013; Harms et al. 2019). Both fossils recorded here provide yet another example of biological stasis in pseudoscorpions because they do not derivate much in morphological features from extant congeners. Other ancient pseudoscorpion families in succinite amber also follow this pattern, such as the families Feaellidae and Pseudogarypidae that may have diverged during the Triassic. Both families are known from succinite ambers but the extinct species can be assigned to modern genera (Feaella and Pseudogarypus) without any doubt (Beier 1937; Hederickx and Boone 2014).

The case is slightly different for some of the more "modern" families with venom glands in their pedipalp fingers that, according to molecular phylogenies, diverged since the Upper Cretaceous, most notably the families Atemnidae, Chernetidae, Cheliferidae and Withiidae in the superfamily 
Table 1 Fossil pseudoscorpions in European succinite ambers and distribution of present-day relatives

\begin{tabular}{|c|c|c|}
\hline Family & Genus & Current distribution \\
\hline \multirow[t]{2}{*}{ Pseudotyrannochthoniidae } & Allochthonis & East Asia \\
\hline & Centrochthonius & Central Asia \\
\hline \multirow[t]{2}{*}{ Chthoniidae } & Chthonius & Europe (entire), North America (U.S.A.), northern Africa, Middle East \\
\hline & Chelignathus & $\dagger$ \\
\hline Feaellidae & Feaella & $\begin{array}{l}\text { Australia, tropical Africa, southern Africa, India, Sri Lanka, Madagas- } \\
\text { car, Seychelles, South America }\end{array}$ \\
\hline Pseudogarypidae & Pseudogarypus & North America (U.S.A.) \\
\hline Neobisiidae & Microcreagris & Asia, North America \\
\hline Neobisiidae & Neobisium & Europe (entire), Middle East, northern Africa \\
\hline Neobisiidae & Roncus & Europe (Mediterranean), Middle East, northern Africa \\
\hline Geogarypidae & Geogarypus & Cosmopolitan (warm temperate to tropical climates) \\
\hline Garypinidae & Garypinus & Europe (Mediterranean), Middle East, southern Africa, Hawaii, Thailand \\
\hline Cheiridiidae & Cheiridium & Cosmopolitan (warm temperate to tropical climates) \\
\hline Withiidae & Beierowithius & $\dagger$ \\
\hline Atemnidae & Progonatemnus & $\dagger$ \\
\hline Chernetidae & Oligochernes & $\dagger$ \\
\hline Cheliferidae & Dichela & $\dagger$ \\
\hline Cheliferidae & Electrochelifer & $\dagger$ \\
\hline Cheliferidae & Pycnochelifer & $\dagger$ \\
\hline Chernetidae & Oligochernes & $\dagger$ \\
\hline Atemnidae & Progonatemnus & $\dagger$ \\
\hline Withiidae & Beierowithius & $\dagger$ \\
\hline
\end{tabular}

Cheliferoidea. Here, the succinite fossils cannot be assigned to extant genera and do not have any morphological matches in the Recent fauna (Table 1). Obviously, morphological evolution was still in progress during the time of amber deposition and these taxa may represent extinct stem-lineages, or ancestral forms to modern fauna that cannot be matched morphologically.

Acknowledgements We thank Carsten Gröhn (Glinde, Germany) and the Geowissenschaftliches Museum, Universität Göttingen (Dr. Alexander Gehler) for access to their collections. Carsten Gröhn also assisted with preparing the specimens for imaging and Carolin Geißler and several student helpers (Universität Hamburg) kindly assisted with the use of equipment. Mark Harvey (Western Australian Museum, Perth, Australia) kindly allowed the study of specimens in his collection for scanning electron microscopy work. We finally thank Jason Dunlop (Museum für Naturkunde Berlin, Germany), Giulio Gardini (Genova, Italy) and an anonymous reviewer for their helpful comments on an earlier draft of this manuscript.

Funding Open Access funding enabled and organized by Projekt DEAL. D. Harms and U. Kotthoff acknowledge the German Science Foundation for support (HA 8785/5 and KO 3944/10).

Open Access This article is licensed under a Creative Commons Attribution 4.0 International License, which permits use, sharing, adaptation, distribution and reproduction in any medium or format, as long as you give appropriate credit to the original author(s) and the source, provide a link to the Creative Commons licence, and indicate if changes were made. The images or other third party material in this article are included in the article's Creative Commons licence, unless indicated otherwise in a credit line to the material. If material is not included in the article's Creative Commons licence and your intended use is not permitted by statutory regulation or exceeds the permitted use, you will need to obtain permission directly from the copyright holder. To view a copy of this licence, visit http://creativecommons.org/licenses/by/4.0/.

\section{References}

Ahrens, J., D. Harms, J.A. Dunlop, and U. Kotthoff. 2019. Pseudoscorpions in Bitterfeld Amber-a survey. Mauritiana 37: 113-147.

Anthony, S.E., C.M. Buddle, and B.J. Sinclair. 2016. Thermal biology and immersion tolerance of the Beringian pseudoscorpion Wyochernes asiaticus. Polar Biology 39: 1351-1355.

Beier, M. 1930. Die Pseudoskorpione der Sammlung Roewer. Zoologischer Anzeiger 91: 284-300.

Beier, M. 1931. Zur Kenntnis der Chthoniiden (Pseudoskorpione). Zoologischer Anzeiger 93: 49-56.

Beier, M. 1937. Pseudoscorpione aus dem baltischen Bernstein. In Festschrift zum 60 Geburtstage von Professor Dr. Embrik Strand 2: 302-316.

Beier, M. 1947. Pseudoskorpione im Baltischen Bernstein und die Untersuchung von Bernstein-Einschlüssen. Mikroskopie, Wien 1 (1946/47): 188-199.

Beier, M. 1979. Pseudoskorpione aus der Küstenprovinz im Osten der USSR. Annalen des Naturhistorischen Museums in Wien 82: 553-557.

Benavides, L.R., J.G. Cosgrove, M.S. Harvey, and G. Giribet. G. 2019. Phylogenomic interrogation resolves the backbone of the 
Pseudoscorpiones Tree of Life. Molecular Phylogenetics and Evolution 139: 106509

Benedict, E.M., and D.R. Malcolm. 1970. Some pseudotyrannochthoniine false scorpions from western North America (Chelonethida: Chthoniidae). Journal of the New York Entomological Society 78: $38-51$.

Chamberlin, J.C. 1929. A synoptic classification of the false scorpions or chela-spinners, with a report on a cosmopolitan collection of the same. Part 1. The Heterosphyronida (Chthoniidae) (Arachnida-Chelonethida). Annals and Magazine of Natural History (10) 4: 50-80.

Chamberlin, J.C. 1931. The arachnid order Chelonethida. Stanford University Publications, Biological Sciences 7: 1-284.

Geer, C. de 1778. Mémoires pour servir à l'histoire des insects (7), 1-456. Stockholm: Grefing \& Hesselberg.

Dunlop, J.A., and P.G. Mitov. 2009. Fossil harvestmen (Arachnida, Opiliones) from Bitterfeld amber. ZooKeys 16: 347-375.

Dunlop, J.A., and P.G. Mitov. 2015. The first fossil cyphophthalmid harvestman from Baltic amber. Arachnologische Mitteilungen 40: $47-54$.

Dunlop, J.A., J. Wunderlich, and G.O. Poinar Jr. 2004. The first fossil opilioacariform mite (Acari: Opilioacariformes) and the first Baltic amber camel spider (Solifugae). Transactions of the Royal Society of Edinburgh, Earth Sciences 94: 261-273.

Dunlop, J.A., U. Kothoff, J.U. Hammel, J. Ahrens, and D. Harms. 2018. Arachnids in Bitterfeld amber: a unique fauna of fossils from the heart of Europe or simply old friends? Evolutionary Systematics 2: 31-44.

Dunlop, J.A., Y. Marusik, and A.P. Vlaskin. 2019. Comparing arachnids in Rovno amber with the Baltic and Bitterfeld deposits. Paleontological Journal 53: 1074-1083.

Gao, Z, and F. Zhang, F. 2013. Description of a new Allochthonius species from China, with a key to the genus (Pseudoscorpiones: Pseudotyrannochthoniidae). Entomologica Fennica 23: 107-112

Gao, Z., Y. Zhang, and F. Zhang. 2016. Two new species of Pseudotyrannochthoniidae, including the first species of Pseudotyrannochthonius (Pseudoscorpiones) from China. Acta Zoologica Academiae Scientiarum Hungaricae 62: 117-131.

Gough, L.J., and J.S. Mills. 1972. The composition of succinite (Baltic amber). Nature 239: 527-528.

Greving, I., F. Wilde, M. Ogurrek, J. Herzen, J.U. Hammel, A. Hipp, F. Friedrich, L. Lottermoser, T. Dose, H. Burmeseter, M. Müller, and F. Beckman. 2014. P05 Imaging Beamtime at PETRA III: First results. Proceedings of SPIE 9212, Developments in X-Ray TomographyIX: 921200.

Gröhn, C. 2020. Ambertop. http://www.ambertop.de/lack_konservier ung.html.

Haibel, A., M. Ogurreck, F. Beckmann, T. Dose, F. Wilde, J. Herzen, M. Müller, A. Schreyer, V. Nazmov, M. Simon, A. Last, and J. Mohr. 2010. Micro-and Nano-Tomography at the GKSS Imaging Beamline at PETRA III." Proceedings of SPIE 7804, Developments in X-Ray Tomography VII: 78040B.

Harms, D. 2018. The origins of diversity in ancient landscapes: deep phylogeographic structuring in a pseudoscorpion (Pseudotyrannochthoniidae: Pseudotyrannochthonius) reflects Plio-Pleistocene climate fluctuations. Zoologischer Anzeiger 273: 112-123.

Harms, D., and J.A. Dunlop. 2017. The fossil history of pseudoscorpions (Arachnida: Pseudoscorpiones). Fossil Record 20: 215-238.

Harms, D., and M.S. Harvey. 2013. Review of the cave-dwelling species of Pseudotyrannochthonius Beier (Arachnida: Pseudoscorpiones: Pseudotyrannochthoniidae) from mainland Australia, with description of two troglobitic species. Australian Journal of Entomology 52: 129-143.

Harms, D., J.D. Roberts, and M.S. Harvey. 2019. Climate variability impacts on diversification processes in a biodiversity hotspot: a phylogeography of ancient pseudoscorpions in southwestern
Australia. Zoological Journal of the Linnean Society 186: 934-949.

Harvey, M.S. 1992. The phylogeny and classification of the Pseudoscorpionida (Chelicerata: Arachnida). Invertebrate Taxonomy 6: $1373-1408$.

Harvey, M.S. 1998. Pseudoscorpion groups with bipolar distributions: a new genus from Tasmania related to the Holarctic Syarinus (Arachnida, Pseudoscorpiones, Syarinidae). Journal of Arachnology 26: 429-441.

Harvey, M.S. 2013. Pseudoscorpions of the World, Version 3.0. Western Australian Museum, Perth. http://www.museum.wa.gov.au/ catalogues/pseudoscorpions [retrieved May 27, 2020]

Harvey, M.S., and F. Štáhlavský. 2009. A review of the pseudoscorpion genus Oreolpium (Pseudoscorpiones, Garypinidae), with remarks on pseudoscorpions with bipolar distributions. Journal of Arachnology 38: 294-308.

Harvey, M.S., J.M. Waldock, R.J. Teale, and J. Webber. 2007. New distribution records of the intertidal pseudoscorpion Parahya submersa (Pseudoscorpiones: Parahyidae). Records of the Western Australian Museum 23: 393-395.

Henderickx, H., and M. Boone. 2014. The first fossil Feaella Ellingsen, 1906, representing an unexpected pseudoscorpion family in Baltic amber (Pseudoscorpiones, Feaellidae). Entomo-Info 25: 5-11.

Hong, Y., T.H. Lee, and W.K. Lee. 1996. The pseudoscorpion family Chthoniidae (Arachnida: Pseudoscorpionida) in Korea, with two new species from the genus Tyrannochthonius. Korean Journal of Systematic Zoology 12: 173-184.

$\mathrm{Hu}$, J., and F. Zhang. 2011. Description of three new species of the genus Allochthonius Chamberlin, 1929 (Pseudoscorpiones: Pseudotyrannohthoniidae) from China. Journal of Threatened Taxa 3: 2167-2176.

Judson, M.L.I. 2012. Reinterpretation of Dracochela deprehendor (Arachnida: Pseudoscorpiones) as a stem-group pseudoscorpion. Palaeontology 55: 261-283.

Judson, M.L.I. 2016. Pseudoscorpions (Arachnida, Chelonethi) in Mexican amber, with a list of extant species associated with mangrove and Hymenaea trees in Chiapas. Boletín de la Sociedad Geológica Mexicana 68: 57-79.

Lee, W.K., and H.Y. Seo. 1995. Soil-inhabiting pseudoscorpions of the genus Allochthonius from Korea. Korean Journal of Systematic Zoology 11: 455-468.

Lytaev, P., A. Hipp, L. Lottermoser, J. Herzen, I. Greving, I. Khokhriakov, S. Meyer-Loges, J. Plewka, J. Burmester, M. Caselle, M. Vogelgesang, S. Chilingaryan, A. Kopmann, M. Balzer, A. Schreyer, and F. Beckmann. 2014. Characterization of the CCD and CMOS cameras for grating-based phase-contrast tomography. Proceedings of SPIE 9212, Developments in X-Ray Tomography IX: 921218.

Mänd, K., K. Muehlenbachs, R.C. McKellar, A.P. Wolfe, and K.O. Konhauser. 2018. Distinct origins for Rovno and Baltic ambers: evidence from carbon and hydrogen stable isotopes. Palaeogeography, Palaeoclimatology, Palaeoecology 505: 265-273.

Morikawa, K. 1954. On some pseudoscorpions in Japanese lime-grottoes. Memoirs of Ehime University 2B(2): 79-87.

Morikawa, K. 1956. Cave pseudoscorpions of Japan (I). Memoirs of Ehime University 2B(2): 271-282.

Morikawa, K. 1970. Results of the speleological survey in South Korea 1966. XX. New pseudoscorpions from South Korea. Bulletin of the National Science Museum of Tokyo 13: 141-148.

Muchmore, W.B. 1967. Pseudotyrannochthoniine pseudoscorpions from the western United States. Transactions of the American Microscopical Society 86: 132-139.

Redikorzev, V. 1918. Pseudoscorpions nouveaux. I. Ezhegodnik Zoologicheskogo Muzeya 22: 91-101. 
Redikorzev, V. 1934. Neue paläarktische Pseudoscorpione. Zoologische Jahrbücher (Abteilung für Systematik, Ökologie und Geographie der Tiere) 65: 423-440.

Sadowski, E.-M., A.R. Schmidt, L.J. Seyfullah, and L. Kunzmann. 2017. Conifers of the 'Baltic amber forest' and their palaeoecological significance. Stapfia 106: 1-73.

Sadowski, E.-M., L.J. Seyfullah, L. Regalado, L.E. Skadell, A. Gehler, C. Gröhn, C. Hoffeins, H.W. Hoffeins, C. Neumann, H. Schneider, and A.R. Schmidt. 2019. How diverse were ferns in the Baltic amber forest? Journal of Systematics and Evolution 57: 305-327.

Schawaller, W. 1978. Neue Pseudoskorpione aus dem Baltischen Bernstein der Stuttgarter Bernsteinsammlung (Arachnida: Pseudoscorpionidea). Stuttgarter Beiträge zur Naturkunde (B) 42: 1-21.

Schawaller, W. 1980. Erstnachweis tertiärer Pseudoskorpione (Chernetidae) in Dominikanischem Bernstein (Stuttgarter Bernsteinsammlung: Arachnida, Pseudoscorpionidea). Stuttgarter Beiträge zur Naturkunde (B) 57: 1-20.

Schawaller, W. 1991. Neue Pseudoskorpion-Funde aus dem NepalHimalaya, III (Arachnida: Pseudoscorpiones). Revue Suisse de Zoologie 98: 769-789.

Schawaller, W. 1995. Review of the pseudoscorpion fauna of China (Arachnida: Pseudoscorpionida). Revue Suisse de Zoologie 102: $1045-1064$.

Schawaller, W., W. Shear, and P.M. Bonamo. 1991. The first Paleozoic pseudoscorpions (Arachnida, Pseudoscorpionida). American Museum Novitates 3009: 1-17.

Schmitt, T., and Z. Varga. 2012. Extra-Mediterranean refugia: the rule and not the exception? Frontiers in Zoology 9: 22.

Shear, W.A., W. Schawaller, and P.M. Bonamo. 1989. Record of Palaeozoic pseudoscorpions. Nature 341: 527-529.
Shi, G.-H., D.A. Grimaldi, G.E. Harlow, J. Wang, M.-C. Yang, W.-Y. Lei, Q. Li, and X.-H. Li. 2012. Age constraints on Burmese amber based on $\mathrm{UePb}$ dating of zircons. Cretaceous Research 37: $155-163$.

Stout, E.C., C.W. Beck, and K.B. Anderson. 2000. Indentification of rumanite (Romanian amber) as thermally altered succinite (Baltic amber). Physics and Chemitry of Minerals 27: 665-678.

Szwedo, J., and E. Sontag. 2013. The flies (Diptera) say that amber from the Gulf of Gdańsk, Bitterfeld and Rovno is the same Baltic amber. Polskie Pismo Entomologiczne 82: 379-388.

Weitschat, W. 2008. Bitterfeld und Baltischer Bernstein aus paläoklimatischer und paläontologischer Sicht. Exkursionsführer und Veröffentlichungen der DGG 236: 88-97.

Weitschat, W., and W. Wichard. 2020. Baltic amber. In Biodiversity of fossils in amber, ed. D. Penney, 80-115. Manchester: Siri Scientific Press.

Wesener, T. 2019. The oldest pill millipede fossil: a species of the Asiatic pill millipede genus Hyleoglomeris in Baltic amber (Diplopoda: Glomerida: Glomeridae). Zoologischer Anzeiger 283: 40-45.

Wriedt, A.L., M.S. Harvey, J.U. Hammel, U. Kotthoff, and D. Harms. 2021. The second chthonioid pseudoscorpion (Pseudoscorpiones: Chthoniidae) from mid-Cretaceous Burmese amber: a new genus with unique morphological features and potential Gondwanan affinities. Journal of Arachnology 48: 311-321.

Xia, F., G. Yang, Q. Zhang, and G. Shi. 2015. Amber. Lives through Time and Space. Bejing: Science Press. (in Chinese with English preface). 